\title{
Sampling Instruction: 100-D-100 and 100-D-30/104 Excavation Sites
}

\author{
MJ Truex \\ VR Vermeul \\ N Qafoku \\ B Lee
}

August 2014

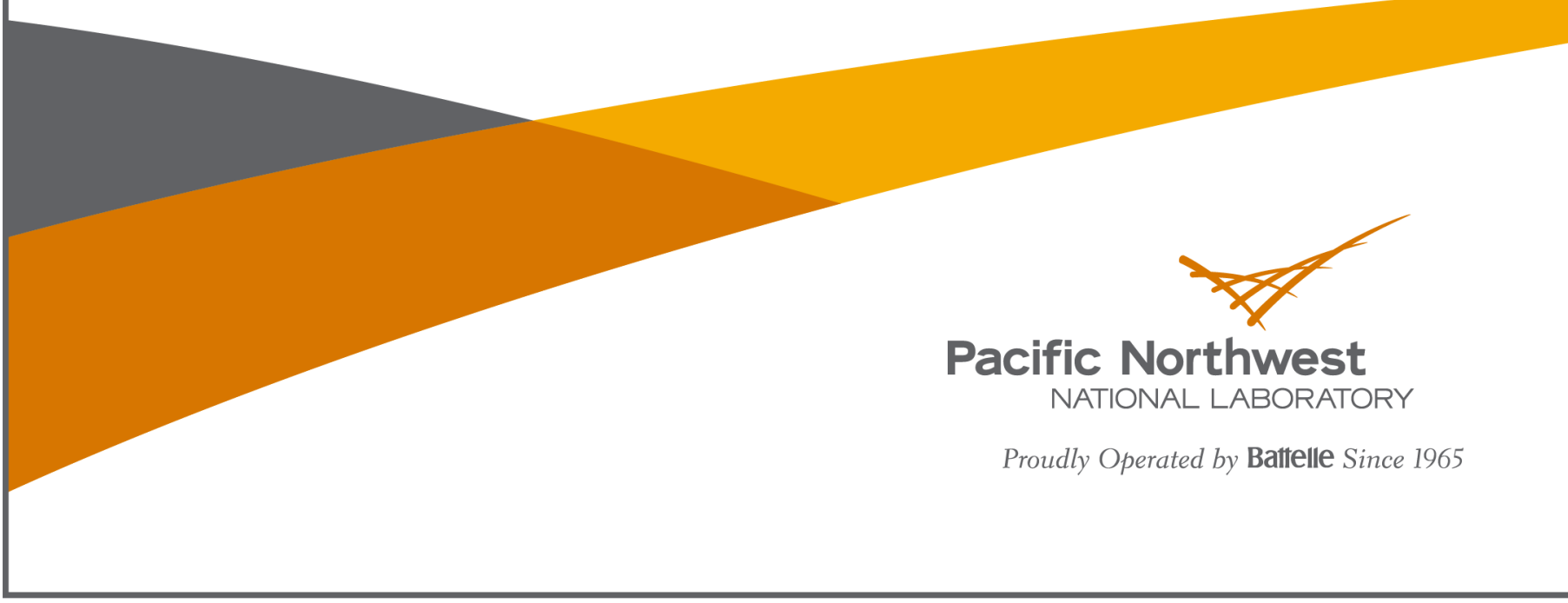




\title{
DISCLAIMER
}

This report was prepared as an account of work sponsored by an agency of the United States Government. Neither the United States Government nor any agency thereof, nor Battelle Memorial Institute, nor any of their employees, makes any warranty, express or implied, or assumes any legal liability or responsibility for the accuracy, completeness, or usefulness of any information, apparatus, product, or process disclosed, or represents that its use would not infringe privately owned rights. Reference herein to any specific commercial product, process, or service by trade name, trademark, manufacturer, or otherwise does not necessarily constitute or imply its endorsement, recommendation, or favoring by the United States Government or any agency thereof, or Battelle Memorial Institute. The views and opinions of authors expressed herein do not necessarily state or reflect those of the United States Government or any agency thereof.

\author{
PACIFIC NORTHWEST NATIONAL LABORATORY \\ operated by \\ BATTELLE \\ for the \\ UNITED STATES DEPARTMENT OF ENERGY \\ under Contract DE-AC05-76RL01830
}

Printed in the United States of America
Available to DOE and DOE contractors from the Office of Scientific and Technical Information,
P.O. Box 62, Oak Ridge, TN 37831-0062;
ph: (865) 576-8401
fax: $(865)$ 576-5728
email: reports@adonis.osti.gov
Available to the public from the National Technical Information Service
5301 Shawnee Rd., Alexandria, VA 22312
ph: (800) 553-NTIS (6847)
email: orders@ntis.gov $<$ http://www.ntis.gov/about/form.aspx $>$
Online ordering: http://www.ntis.gov

This document was printed on recycled paper. 


\title{
Sampling Instruction: 100-D-100 and 100-D-30/104 Excavation Sites
}

\author{
MJ Truex \\ VR Vermeul \\ N Qafoku \\ B Lee
}

August 2014

Prepared for

the U.S. Department of Energy

under Contract DE-AC05-76RL01830

Pacific Northwest National Laboratory

Richland, Washington 99352 



\section{Contents}

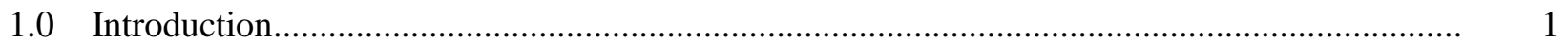

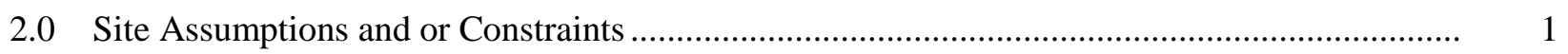

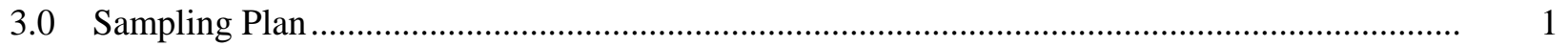

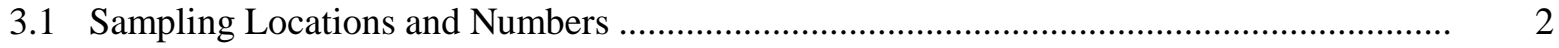

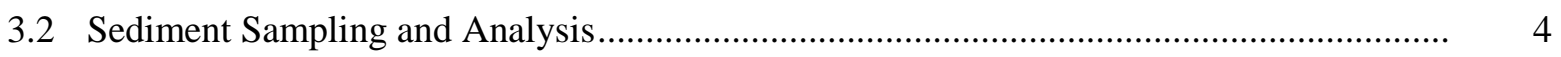

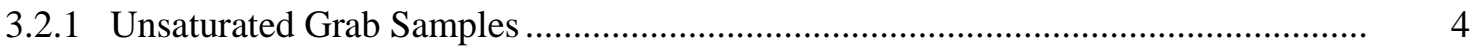

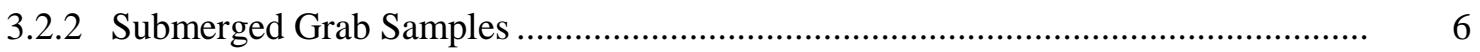

3.3 Groundwater Sampling and Analysis ...................................................................... 7

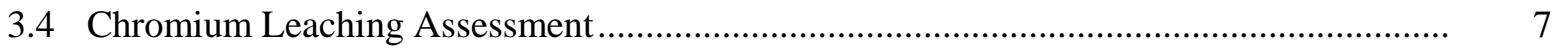

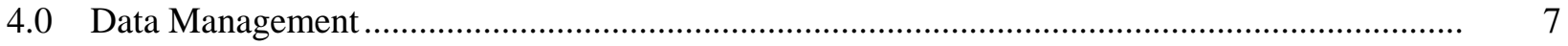

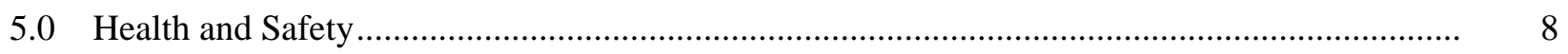

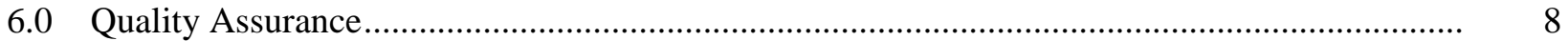

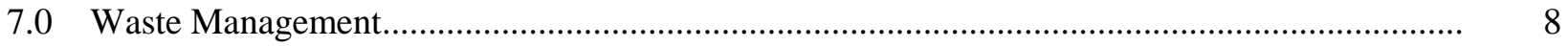

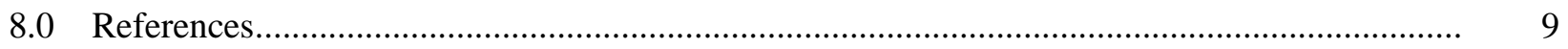




\section{Figures}

1 Sidewall unsaturated sample locations for 100-D-30/104 and 100-D-100 .............................. 2

2 Submerged and groundwater sample locations for 100-D-30/104 ......................................... 3

\section{Tables}

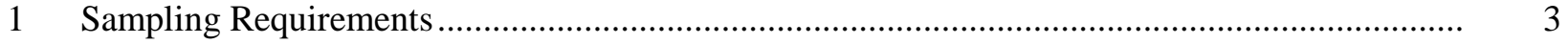

2 Unsaturated Sediment Sample Analytical Requirements ..................................................... 5

3 Unsaturated Sediment Sample Analytical Requirements ........................................................ 6

4 Aqueous Sample Analytical Requirements ...................................................................... 7 


\subsection{Introduction}

Deep excavation of soil at the 100-D-100 and 100-D-30/104 waste sites to remove hexavalent chromium (Cr(VI)) contamination has been conducted, with the excavations reaching the water table. Exposed sediments near and at the bottom of the excavation show visual indications of potential $\mathrm{Cr}(\mathrm{VI})$ contamination. Thus, sampling and analysis are required to evaluate the nature of this contamination to provide input to assessment of potential impact to groundwater. Several types of data are needed to assess the $\mathrm{Cr}(\mathrm{VI})$ contamination. These data include 1) $\mathrm{Cr}(\mathrm{VI})$ and $\mathrm{Cr}(\mathrm{III})$ concentrations for sediment samples at selected locations as a function of sediment particle size groups, 2) chromium precipitate mineralogy, and 3) presence/absence identification for algae in sediment samples and samples from groundwater that is now exposed to the atmosphere at the bottom of the excavation. This plan outlines the sampling and analysis procedures that will be conducted to obtain these data.

\subsection{Site Assumptions and or Constraints}

The following items are assumptions and constraints for the project.

- Chromium is the only contaminant of concern in the sediment and groundwater. Other contaminants will not be a health and safety, waste disposal, or operational concern.

- There will be vehicle access to the bottom of the excavation.

- Water and sediment samples will be retrieved for analysis in the laboratory.

- Samples of ponded water in the bottom of the excavation will be collected from the water's edge (i.e., wading to depths of more than one foot will not be required).

- Duplicate samples will be taken and provided, in the field, to Washington Department of Ecology for their analysis.

- A DOE-RL staff member or designee will be present during sampling and will provide direction on specific sampling locations.

\subsection{Sampling Plan}

There are two elements to the sampling plan and a contingency element.

Element 1. Sediment sampling of unsaturated and submerged samples

Element 2. Groundwater sampling from the exposed groundwater in the excavation

Contingency Element. Sediment chromium leaching evaluation

Sampling plan elements are discussed in more detail in the following sections. 


\subsection{Sampling Locations and Numbers}

Visual cues can be used to guide selection of appropriate sample material for collection of unsaturated sediments. General target locations for unsaturated sidewall samples are identified on Figure 1. Submerged samples will be collected at the locations shown in Figure 2.

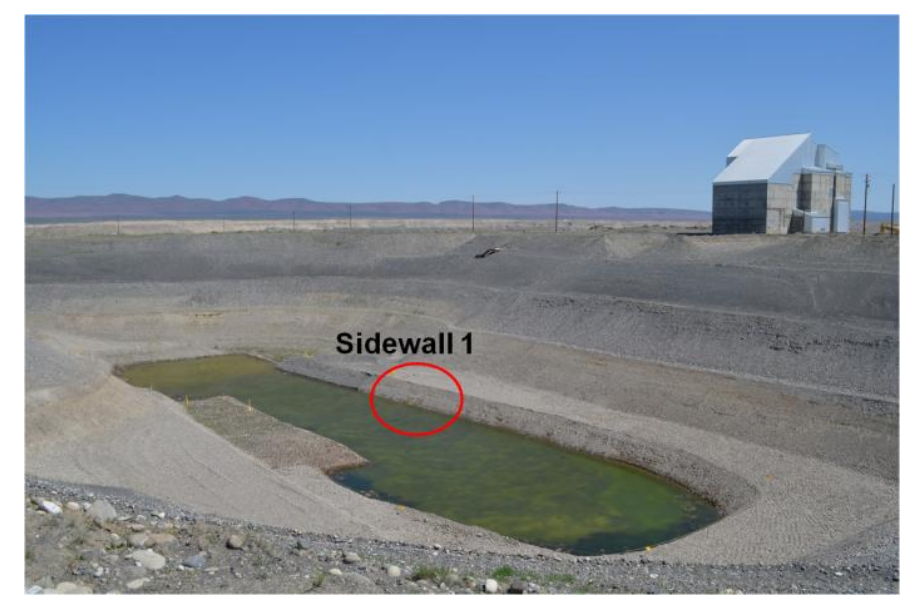

$100-\mathrm{D}-30 / 104(a)$

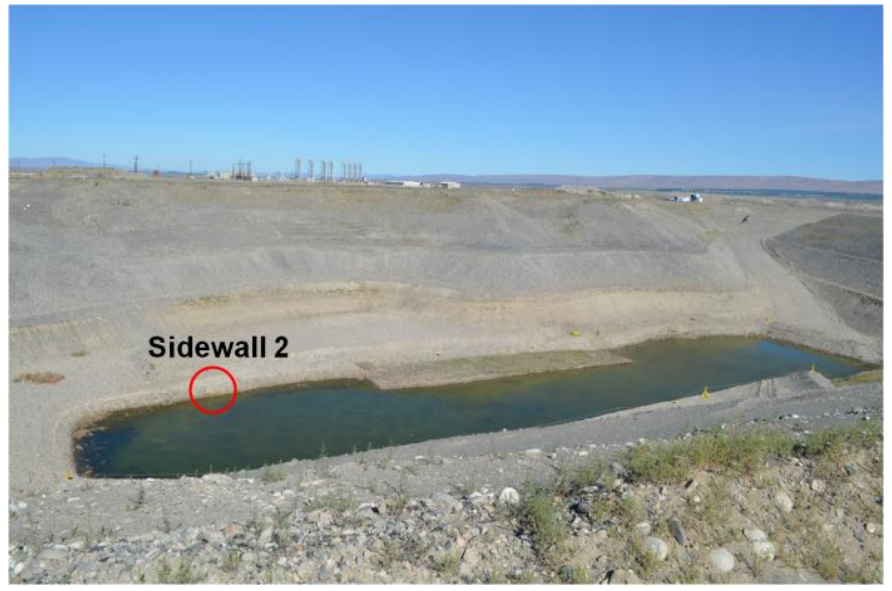

$100-\mathrm{D}-30 / 104(\mathrm{~b})$

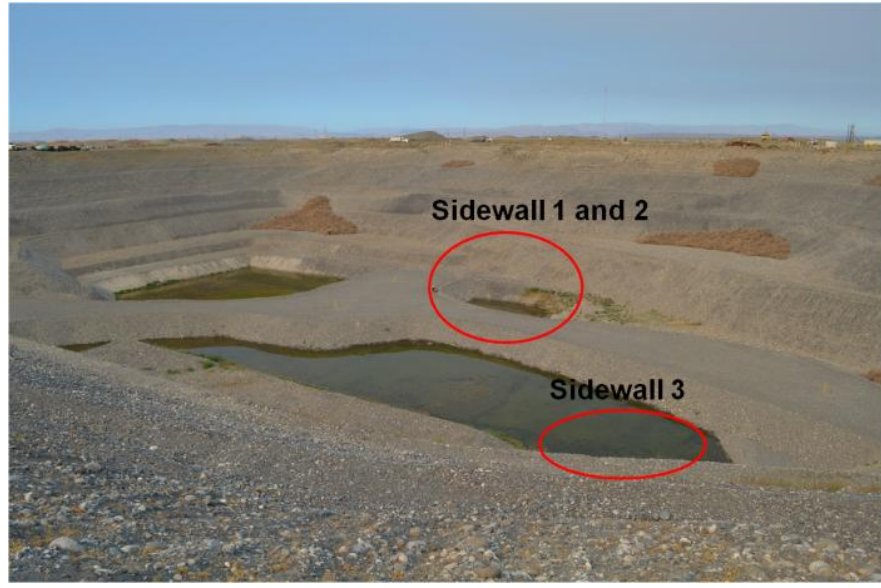

$100-\mathrm{D}-100(\mathrm{c})$

Figure 1. Sidewall unsaturated sample locations for 100-D-30/104 (a and b) and 100-D-100 (c). 


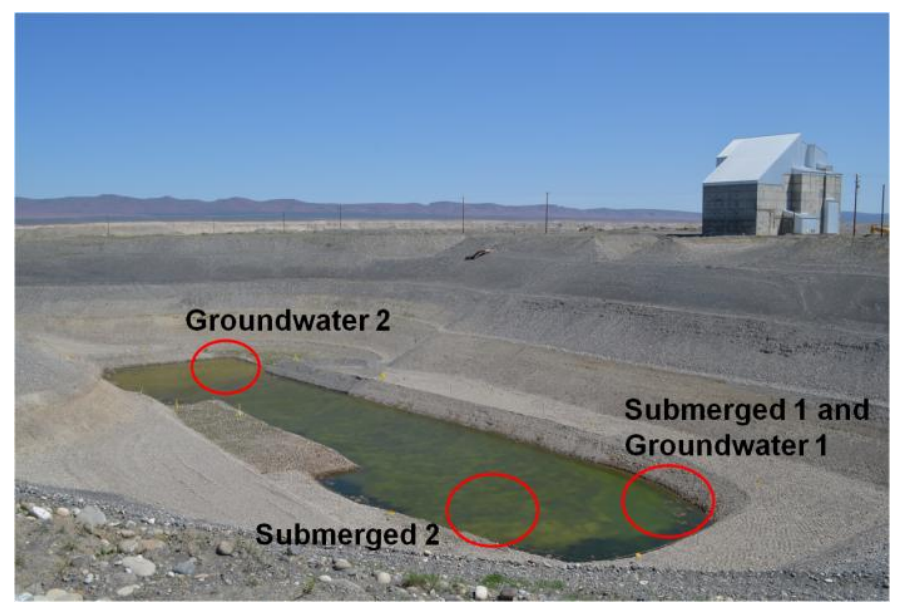

Figure 2. Submerged and groundwater sample locations for 100-D-30/104.

Sample quantities and containers are shown in Table 1. At the unsaturated sample locations, 3 bulk grab samples will be collected and up to 2 focused samples will be collected. All bulk grab samples will be used for $\mathrm{Cr}(\mathrm{VI})$ and $\mathrm{Cr}(\mathrm{III})$ analysis (Section 3.2.1). Sufficient bulk grab sample will be obtained so that column leaching tests (Section 3.4) could be performed if needed. Subsamples from up to 5 of the bulk grab samples and up to 5 of the focused samples will be submitted for chromium precipitate analysis (Section 3.2.1). Groundwater samples will be collected for the analyses described in Section 3.3.

Table 1. Sampling Requirements

\begin{tabular}{|c|c|c|c|c|}
\hline Location & Number & Type & Volume/Container & Preservation \\
\hline \multirow{2}{*}{$\begin{array}{l}\text { 100-D-30/104 } \\
\text { Sidewall } 1\end{array}$} & 3 & Bulk grab & 0.7 -gallon plastic bucket & $4^{\circ} \mathrm{C}$ \\
\hline & Up to 2 & Focused sample & $1 \mathrm{~L}$ wide-mouth bottle & $4^{\circ} \mathrm{C}$ \\
\hline \multirow{2}{*}{$\begin{array}{l}\text { 100-D-30/104 } \\
\text { Sidewall } 2\end{array}$} & 3 & Bulk grab & 0.7-gallon plastic bucket & $4^{\circ} \mathrm{C}$ \\
\hline & Up to 2 & Focused sample & $1 \mathrm{~L}$ wide-mouth bottle & $4^{\circ} \mathrm{C}$ \\
\hline \multirow{3}{*}{$\begin{array}{l}\text { 100-D-30/104 } \\
\text { Submerged } 1\end{array}$} & 1 & Freeze core & 0.7 -gallon plastic bucket & $4^{\circ} \mathrm{C}$ \\
\hline & 1 & $\begin{array}{l}\text { Groundwater/Cr } \\
\text { (Groundwater 1) }\end{array}$ & $\begin{array}{l}1 \mathrm{~L} \text { wide-mouth bottle } \\
\text { (acid washed) }\end{array}$ & $\begin{array}{l}4^{\circ} \mathrm{C} \text { (filtered on } \\
\text { receipt in lab) }\end{array}$ \\
\hline & 1 & $\begin{array}{l}\text { Groundwater } \\
\text { /algae } \\
\text { (Groundwater 1) }\end{array}$ & $1 \mathrm{~L}$ wide-mouth bottle & $4^{\circ} \mathrm{C}$ \\
\hline $\begin{array}{l}\text { 100-D-30/104 } \\
\text { Submerged } 2\end{array}$ & 1 & Freeze core & 0.7-gallon plastic bucket & $4^{\circ} \mathrm{C}$ \\
\hline $\begin{array}{l}100-D-30 / 104 \\
\text { Groundwater } 2\end{array}$ & 1 & $\begin{array}{l}\text { Groundwater } \\
\text { /algae }\end{array}$ & $1 \mathrm{~L}$ wide-mouth bottle & $4^{\circ} \mathrm{C}$ \\
\hline \multirow[t]{2}{*}{$\begin{array}{l}\text { 100-D-100 } \\
\text { Groundwater }\end{array}$} & 1 & Groundwater/Cr & $\begin{array}{l}1 \mathrm{~L} \text { wide-mouth bottle } \\
\text { (acid washed) }\end{array}$ & $\begin{array}{l}4^{\circ} \mathrm{C} \text { (filtered on } \\
\text { receipt in lab) }\end{array}$ \\
\hline & 1 & $\begin{array}{l}\text { Groundwater } \\
\text { /algae }\end{array}$ & $1 \mathrm{~L}$ wide-mouth bottle & $4^{\circ} \mathrm{C}$ \\
\hline \multirow{2}{*}{$\begin{array}{l}\text { 100-D-100 } \\
\text { Sidewall } 1\end{array}$} & 3 & Bulk grab & 0.7-gallon plastic bucket & $4^{\circ} \mathrm{C}$ \\
\hline & Up to 2 & Focused sample & $1 \mathrm{~L}$ wide-mouth bottle & $4^{\circ} \mathrm{C}$ \\
\hline \multirow{2}{*}{$\begin{array}{l}100-D-100 \\
\text { Sidewall } 2\end{array}$} & 3 & Bulk grab & 0.7-gallon plastic bucket & $4^{\circ} \mathrm{C}$ \\
\hline & Up to 2 & Focused sample & $1 \mathrm{~L}$ wide-mouth bottle & $4^{\circ} \mathrm{C}$ \\
\hline \multirow[t]{2}{*}{$\begin{array}{l}100-D-100 \\
\text { Sidewall } 3\end{array}$} & $\begin{array}{l}3 \text { capillary fringe } \\
3 \text { above fringe }\end{array}$ & Bulk grab & 0.7-gallon plastic bucket & $4^{\circ} \mathrm{C}$ \\
\hline & Up to 2 & Focused sample & $1 \mathrm{~L}$ wide-mouth bottle & $4^{\circ} \mathrm{C}$ \\
\hline
\end{tabular}




\subsection{Sediment Sampling and Analysis}

Two types of sediment sampling will be conducted. One type of sediment sampling will be at locations above the current water table, for which an unsaturated grab sample can be obtained directly with standard surface soil sampling techniques. The other type of sampling will be for sediments at the bottom of the excavation, which is currently underneath a shallow surface water expression of the groundwater. The submerged samples will be collected using techniques typically applied for collecting river sediment grab samples. Sampling implements will be new or decontaminated prior to use in sampling.

\subsubsection{Unsaturated Grab Samples}

At the specific locations selected by the DOE-RL representative or designee, samples will be collected by scooping sediment into a sample container (i.e., sediment will not be cored). Sample containers will be transported to the laboratory, where sieving will be used to separate the sample into $<4 \mathrm{~mm}$ and $\geq 4 \mathrm{~mm}$ particle size groups (noting that sieving may retain some aggregates of particles $<4 \mathrm{~mm}$ within the $\geq 4 \mathrm{~mm}$ group). Depending on conditions at the time of sampling and as directed by the DOE-RL representative (or designee), some specific gravel-size material may be collected separately, if it shows indication of surface contamination.

Samples from the two particle size groups and, if appropriate, scrapings from the surface of gravelsize material will be analyzed for $\mathrm{Cr}(\mathrm{VI})$ and $\mathrm{Cr}$ (total), as designated in Table 2. Selected samples with expected high surface precipitate concentrations will be used for identification of chromium precipitates, as designated in Table 2. 
Table 2. Unsaturated Sediment Sample Analytical Requirements

\begin{tabular}{|c|c|c|c|c|c|}
\hline Parameter & Samples & Analysis Method & $\begin{array}{l}\text { Detection } \\
\text { Limit }\end{array}$ & $\begin{array}{l}\text { Typical } \\
\text { Precision/ } \\
\text { Accuracy }\end{array}$ & $\begin{array}{c}\text { QC } \\
\text { Requirements }\end{array}$ \\
\hline $\mathrm{Cr}$ (total) & $\begin{array}{l}\text { Water extraction: }<4 \\
\text { mm and }>4 \mathrm{~mm} \\
\text { particle size groups } \\
\text { (36), scrapings (up to } \\
10 \text { ) } \\
\text { Method } 3060 \mathrm{~A}:<4 \\
\mathrm{~mm} \text { particle size group } \\
\text { (18), scrapings (up to } \\
\text { 10) }\end{array}$ & $\begin{array}{l}\text { ICP-MS, (EPA Method } \\
6020 \mathrm{~A} \text { ) of water } \\
\text { extraction and EPA } \\
\text { Method } 3060 \mathrm{~A} \\
\text { alkaline digestion } \\
\text { extraction }\end{array}$ & $\begin{array}{l}1 \mu \mathrm{g} / \mathrm{L} \text { for } \\
\text { trace elements }\end{array}$ & $\pm 10 \%$ & $\begin{array}{l}\text { Daily } \\
\text { calibration; } \\
\text { blanks, plus } \\
\text { duplicates and } \\
\text { matrix spikes at } \\
10 \% \text { level }\end{array}$ \\
\hline $\mathrm{Cr}(\mathrm{VI})$ & $\begin{array}{l}\text { Water extraction: }<4 \\
\text { mm and }>4 \mathrm{~mm} \\
\text { particle size groups } \\
\text { (36), scrapings (up to } \\
\text { 10) } \\
\text { Method } 3060 \mathrm{~A}:<4 \\
\mathrm{~mm} \text { particle size group } \\
\text { (18), scrapings (up to } \\
\text { 10) }\end{array}$ & $\begin{array}{l}\text { EPA Method } 7196 \\
\text { (colorimetric) of water } \\
\text { extraction and EPA } \\
\text { Method } 3060 \mathrm{~A} \\
\text { alkaline digestion } \\
\text { extraction }\end{array}$ & $10 \mu \mathrm{g} / \mathrm{L}$ & $\pm 10 \mu \mathrm{g} / \mathrm{L}$ & $\begin{array}{l}\text { Blanks, } \\
\text { duplicates, and } \\
\text { matrix spikes } \\
(3060 \mathrm{~A} \text { only) at } \\
10 \% \text { level }\end{array}$ \\
\hline $\begin{array}{l}\text { Chromium } \\
\text { precipitate } \\
\text { identification }\end{array}$ & $\begin{array}{l}<4 \mathrm{~mm} \text { particle size } \\
\text { group (up to 5), } \\
\text { scrapings (up to 5) }\end{array}$ & $\begin{array}{l}\text { SEM / EDS / TEM / } \\
\text { SAED and potentially } \\
\text { XPS (see text for } \\
\text { details) }\end{array}$ & $\begin{array}{l}\mathrm{mg} / \mathrm{L} \text { level of } \\
\text { chromium } \\
\text { contamination }\end{array}$ & $\mathrm{N} / \mathrm{A}$ & $\mathrm{N} / \mathrm{A}$ \\
\hline
\end{tabular}

$\mathrm{Cr}(\mathrm{VI})$-containing solid phases may be formed in the sediments under favorable conditions. These solid phases include barium chromate $\left(\mathrm{BaCrO}_{4}\right)$ (a light yellow powder), and other chromate minerals [e.g., $\left.\mathrm{Ba}\left(\mathrm{SO}_{4}, \mathrm{CrO}_{4}\right)\right]$ with varying solubility. $\mathrm{Cr}(\mathrm{VI})$ may also be incorporated into other mineral phases. For example, $\mathrm{Cr}(\mathrm{VI})$ may co-precipitate with calcite, and the concentration of chromium incorporated into calcite increases with increasing chromium concentration in solution. In this case, significant distortion or disruption of local coordination is required to accommodate $\mathrm{CrO}_{4}{ }^{2-}$ in the calcite structure. Finally, sorption of $\mathrm{Cr}(\mathrm{VI})$ to soil mineral surfaces may also occur. Scanning electron microscopy (SEM) combined with electron dispersive spectroscopy (EDS) will be used to initially inspect sediment grains and their surfaces for Cr-rich zones. The mineral phases in chromium-rich zones can then be identified with transmission electron microscopy (TEM), combined with selected area electron diffraction (SAED). This technique will provide information to determine chromium association with barium and/or calcium and to describe the morphological features of potential $\mathrm{Cr}(\mathrm{VI})$ bearing minerals that may control their solubility. Based on this information, the nature of chromium precipitates and the associated solubility control on dissolution rate can be inferred.

If warranted based on bulk sample data, solid-phase analysis for $\mathrm{Cr}(\mathrm{III})$ in chromium precipitates may also be evaluated. Potential precipitates include $\mathrm{Cr}(\mathrm{III})$ phases $\left[\mathrm{Cr}(\mathrm{OH})_{3}\right]$ or co-precipitation of $\mathrm{Fe}(\mathrm{III}) / \mathrm{Cr}(\mathrm{III})$ solid solutions [e.g., $\left.(\mathrm{Fe}, \mathrm{Cr})(\mathrm{OH})_{3}\right]$. Anthropomorphic $\mathrm{Cr}(\mathrm{VI})$ may be reduced by $\mathrm{Fe}(\mathrm{II})$ bearing minerals, such as Fe oxides (e.g., magnetite), phyllosilicates (e.g., biotite and chlorite) and serpentine subgroup minerals (e.g., antigorite and lizardite) through homogeneous and/or heterogeneous electron transfer reactions occurring at the micron scale. Biological reduction of $\mathrm{Cr}$ (VI) to $\mathrm{Cr}$ (III) is also possible. To evaluate Cr(III) precipitates, SEM combined with EDS will be used to initially inspect sediment grains and their surfaces for chromium-rich zones. The mineral phases in chromium-rich zones 
can then be identified with TEM, combined with SAED, as described above for Cr(VI) precipitates. $\mathrm{X}$-ray photoelectron spectroscopy (XPS) can be used to determine the $\mathrm{Cr}(\mathrm{III}) / \mathrm{Cr}(\mathrm{VI})$ ratio in the chromium-rich zones.

\subsubsection{Submerged Grab Samples}

The submerged grab samples will be collected at the specific location directed by the DOE-RL representative or designee. Prior to sediment sampling, a grab sample of groundwater will be collected from above the designated submerged sediment sampling location (see Section 3.3). A liquid-nitrogen freeze rod will be used to collected sediment with emphasis on obtaining the top sediment layer. For the liquid-nitrogen freeze rod sampling, a hollow stainless steel tube will be driven into the sediment to a depth of approximately $25 \mathrm{~cm}$ below the bed surface. The tubes are $152 \mathrm{~cm}$ long with a $2.4-\mathrm{cm}$ inside diameter and a 3.3-cm outside diameter. Liquid nitrogen will be dispensed into the tubes over a 10- to 20-minute time span to freeze the sediment around the tubes. The tubes will then be removed from the sediment along with the frozen sediment sample. Sample material will be knocked off the rod into the sampling container. Freezing time, liquid nitrogen volume, and insertion depth may be adjusted based on field results from the initial sampling attempt. The goal will be to obtain a sample of a few $\mathrm{kg}$ from within the top $30 \mathrm{~cm}$ of the sediment. A frozen sediment and water sample will be obtained and shipped to the laboratory. The water will be separated after the sample thaws for analysis with groundwater samples (Section 3.3). Sediment will be analyzed as designated in Table 3.

Table 3. Unsaturated Sediment Sample Analytical Requirements

\begin{tabular}{|c|c|c|c|c|c|}
\hline Parameter & Samples & Analysis Method & $\begin{array}{l}\text { Detection } \\
\text { Limit }\end{array}$ & $\begin{array}{c}\text { Typical } \\
\text { Precision/ } \\
\text { Accuracy }\end{array}$ & $\begin{array}{c}\text { QC } \\
\text { Requirements }\end{array}$ \\
\hline$\overline{\mathrm{Cr} \text { (total) }}$ & $\begin{array}{l}\text { Water extraction: }<4 \\
\mathrm{~mm} \text { and }>4 \mathrm{~mm} \\
\text { particle size groups } \\
\text { (36), scrapings (up to } \\
10 \text { ) } \\
\text { Method } 3060 \mathrm{~A}:<4 \\
\mathrm{~mm} \text { particle size group } \\
\text { (18), scrapings (up to } \\
10 \text { ) }\end{array}$ & $\begin{array}{l}\text { ICP-MS, (EPA Method } \\
6020 \mathrm{~A} \text { ) of water } \\
\text { extraction and EPA } \\
\text { Method } 3060 \mathrm{~A} \\
\text { alkaline digestion } \\
\text { extraction }\end{array}$ & $\begin{array}{l}1 \mu \mathrm{g} / \mathrm{L} \text { for } \\
\text { trace elements }\end{array}$ & $\pm 10 \%$ & $\begin{array}{l}\text { Daily } \\
\text { calibration; } \\
\text { blanks, plus } \\
\text { duplicates and } \\
\text { matrix spikes at } \\
10 \% \text { level }\end{array}$ \\
\hline $\mathrm{Cr}(\mathrm{VI})$ & $\begin{array}{l}\text { Water extraction: }<4 \\
\text { mm and }>4 \mathrm{~mm} \\
\text { particle size groups } \\
\text { (36), scrapings (up to } \\
\text { 10) } \\
\text { Method } 3060 \mathrm{~A}:<4 \\
\mathrm{~mm} \text { particle size group } \\
\text { (18), scrapings (up to } \\
\text { 10) }\end{array}$ & $\begin{array}{l}\text { EPA Method } 7196 \\
\text { (colorimetric) of water } \\
\text { extraction and EPA } \\
\text { Method 3060A } \\
\text { alkaline digestion } \\
\text { extraction }\end{array}$ & $10 \mu \mathrm{g} / \mathrm{L}$ & $\pm 10 \mu \mathrm{g} / \mathrm{L}$ & $\begin{array}{l}\text { Blanks, } \\
\text { duplicates, and } \\
\text { matrix spikes } \\
(3060 \mathrm{~A} \text { only) at } \\
10 \% \text { level }\end{array}$ \\
\hline $\begin{array}{l}\text { Algae } \\
\text { identification }{ }^{1}\end{array}$ & $\begin{array}{l}<4 \mathrm{~mm} \text { and }>4 \mathrm{~mm} \\
\text { particle size groups (4) }\end{array}$ & $\begin{array}{l}\text { Phase contrast } \\
\text { microscopy }\end{array}$ & $\begin{array}{l}100 \mathrm{~s} \text { of } \\
\text { cells } / \mathrm{mL}\end{array}$ & $\begin{array}{l}100 \text { cells / } \\
\mathrm{ml} \text { of water }\end{array}$ & $\pm 10 \%$ \\
\hline
\end{tabular}

${ }^{1}$ Sediment samples will be subjected to agitation with a cell releasing buffer to obtain an aqueous sample for microscopy analysis. 


\subsection{Groundwater Sampling and Analysis}

Plastic sample bottles will be used to retrieve aqueous samples from the surface water ( 2 samples from 100-D-30/104 and 1 sample from 100-D-100 as designated in Table 1). In addition, water drained from the submerged samples will also be collected for analysis. This set of samples (5) will be analyzed immediately on receipt of the samples in the laboratory (same day as sampling) for $\mathrm{Cr}(\mathrm{VI})$, as described in Table 4. This set of samples (5) will also be analyzed in the laboratory for algae identification (Table 4).

Table 4. Aqueous Sample Analytical Requirements

\begin{tabular}{|l|l|l|c|c|}
\hline \multicolumn{1}{|c|}{ Parameter } & Analysis Method & \multicolumn{1}{c|}{ Detection Limit } & $\begin{array}{c}\text { Typical } \\
\text { Precision/Accuracy }\end{array}$ & $\begin{array}{c}\text { QC } \\
\text { Requirements }\end{array}$ \\
\hline Algae identification & $\begin{array}{l}\text { Phase contrast } \\
\text { microscopy }\end{array}$ & $100 \mathrm{~s}$ of cells $/ \mathrm{mL}$ & 100 cells/mL of water & $\pm 10 \%$ \\
\hline $\mathrm{Cr}(\mathrm{VI})$ & $\begin{array}{l}\text { EPA Method } 7196 \\
\text { (colorimetric) }\end{array}$ & $10 \mu \mathrm{g} / \mathrm{L}$ & $\pm 10 \mu \mathrm{g} / \mathrm{L}$ & $\begin{array}{l}\text { Blanks, duplicates } \\
\text { at } 10 \% \text { level }\end{array}$ \\
\hline
\end{tabular}

\subsection{Chromium Leaching Assessment}

Depending on the results from analyses described in Sections 3.1 and 3.3, chromium leaching studies may also be conducted for sediment samples. Samples selected for leaching studies will be sieved to remove particles greater than $4 \mathrm{~mm}$. The total sediment sample weight including larger particles will be retained for use in data analysis calculations. The field moisture content on the $<4 \mathrm{~mm}$ fraction will be determined by wet and dry weights using a subsample. Sieved material will be packed into 1-inch diameter by 6-inch soil columns. High performance liquid chromatography pumps will be used to inject simulated groundwater through the column with a residence time of about 4 hours. Effluent will be collected using a fraction collector and selected time interval samples will be analyzed for chromate and $\mathrm{pH}$. At selected times, flow will be stopped for greater than 12 hours as a means to evaluate the chromate release rate from sediment. These tests will be conducted in a manner that allows comparison to laboratory testing results from leaching studies of sediment sample from the aquifer beneath the 100-D-100 excavation.

\subsection{Data Management}

A project-specific database will be developed and maintained to collect, organize, store, verify/validate, and manage analytical laboratory data and/or field measurements for environmental samples. These data will be stored electronically as Microsoft Excel ${ }^{\circledR}$ spreadsheet files and hard copies will be maintained in the project files. A project data custodian will be designated to control and maintain the data. The following data will be maintained, at a minimum, as part of the database:

- Sample identifier

- Sample location

- Sample medium type

- Sampling date

- Analysis date 
- Laboratory name

- Analyte name

- Concentration value

- Measurement unit.

Data will be managed in accordance with applicable PNNL How Do I (HDI) subject areas and quality assurance protocols. Data will be made available for entry into the Hanford Environmental Information System (HEIS).

\subsection{Health and Safety}

Safety and health issues relating to these work elements are addressed in a project-specific health and safety plan (HASP) that identifies industrial safety and health hazards, as well as control measures for those hazards. The HASP includes specific training requirements for all site workers and visitors. A prejob safety briefing will be held prior to start of work and a daily tailgate safety meeting will be held to discuss any task-specific safety concerns. In addition, a sampling-specific HASP will be used to guide activities for the liquid-nitrogen freeze rod sampling.

\subsection{Quality Assurance}

The work will comply with applicable subject areas of the PNNL HDI. HDI is a web-based system for communicating PNNL's management systems and procedures through subject areas. PNNL's Quality Assurance Program is based on the requirements of DOE Order 414.1C, "Quality Assurance," and 10 CFR 830, Subpart A, "Quality Assurance Requirements.” Additional specific quality assurance requirements are provided in sampling and analysis tables in Section 3.0.

\subsection{Waste Management}

All investigation-derived waste (IDW) will be handled in accordance with PNNL waste management procedures and applicable Hanford Site requirements. Expected waste streams may include the following:

- Miscellaneous solid waste such as filters, wipes, gloves and other personal protective equipment, sampling and measuring equipment, pumps, pipe, wire, or plastic sheeting

- Sediment samples

- Groundwater samples

- Decontamination solutions

- Analytical wastes 
Miscellaneous solid waste that has contacted potentially contaminated groundwater will be segregated from other materials and will be transported to PNNL facilities for disposal based on a waste designation per internal PNNL waste management procedures. Waste will be designated in accordance with WAC 173-303 using a combination of process knowledge, historical analytical data, and analyses of samples collected from the site.

Based on available soil contamination data collected during excavation, the hazardous waste designation for hexavalent chromium - which is the only identified constituent likely to trigger a hazardous waste designation - will probably be exceeded and thus, all investigation derived sampling waste will be disposed of in accordance with PNNL procedures for disposal of such waste. During sampling of the surface water, any excess water that has not been amended in any way will be discharged back to the surface water at the end of sampling.

\subsection{References}

10 CFR 830, Subpart A. 2012. "Quality Assurance Requirements.” Code of Federal Regulations, U.S. Environmental Protection Agency.

DOE Order 414.1C. 2005. “Quality Assurance.” U.S. Department of Energy, Washington, D.C.

EPA. 1993. Method 300.0 - Determination of Inorganic Anions by Ion Chromatography. EPA Method 300.0, U.S. Environmental Protection Agency, Cincinnati, Ohio.

WAC 173-303. 2009. "Dangerous Waste Regulations." Washington Administrative Code, Olympia, Washington. 


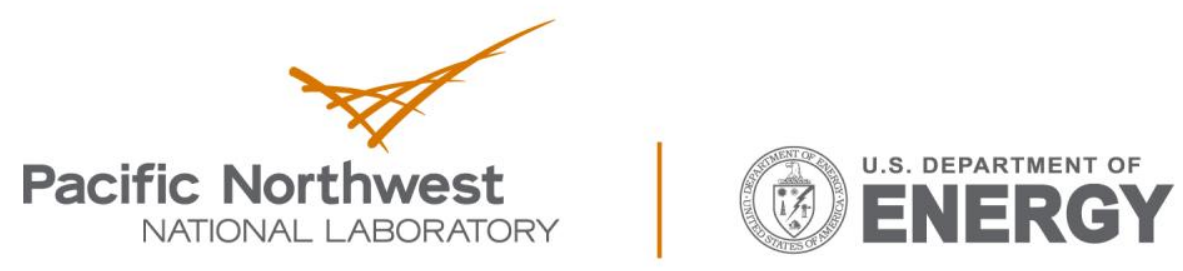

Proudly Operated by Battelle Since 1965

902 Battelle Boulevard

P.O. Box 999

Richland, WA 99352

1-888-375-PNNL (7665)

www.pnnl.gov 